\author{
УДК 786.2 \\ DOI https://doi.org/10.31723/2524-0447-2021-32-1-17
}

\author{
Володимир Іванович Бордонюк \\ ORCID: 0000-0003-0634-6910 \\ кандидат мистецтвознавства,
}

в. о. доцента кафедри загального та спеціалізованого фортепіано

Одеської національної музичної академії імені А. В. Нежданової

bordonukv@gmail.com

\title{
КОНЦЕПЦІЯ ЦИКЛІЗАЦІЇ ПРЕЛЮДІЙ Ф. ШОПЕНА ТА ЇХ ВЗАЕМОЗВ'ЯЗКИ ІЗ ЦИКЛОМ «ДОБРЕ ТЕМПЕРОВАНИЙ КЛАВІР» Й. С. БАХА
}

Мета роботи - виявлення смислової унікальності циклу Прелюдій Ф. Шопена та знаходження їх глибинних взаємозв'язків з поліфонічним циклом «Добре темперований клавір» Й.С. Баха. Методологія роботи комплексна і полягає в об'єднанні основ музикознавчого, мистеитвознавчого та історико-культурологічного дослідження, базується на позиціях інтонаційного підходу школи Б. Асаф'єва і його послідовників. Наукова новизна дослідження визначена його аналітичним ракурсом, що зосереджений на виявленні бахівського і романтичного принципів циклізаціі та дозволяє виявити в низці Прелюдій Ф. Шопена різні грані образу, які не вловлюються під час розгляді іх поза контекстом будови циклу загалом. Висновки. У Прелюдіях ор. 28 Ф. Шопен чітко склав послідовність хроматичних 24 тональностей, у нагадування згаданого ииклу Й.С. Баха. Структурне і смислове співвідношення «прелюдіяфуга» підказано не тільки характером замислу, тобто чимось, що перебуває поза «матерією» твору. Установка на бахівський иикл «запрограмована» в Першій прелюдії і простежується протягом усіх 24 n'єс. Але, заклавши очевидний знак подоби, Ф. Шопен спеціально також $i$ розмежував метод бахівського бароко і логіку романтичного прагнення до Краси, до космічної масштабності образу. Краса і просторовість надземного сенсу від часів стародавньої риторики символізувалася за допомогою квінтової інтерваліки: квінтове коло визначило стрижневу інтервальну конструкцію Прелюдій Ф. Шопена, які відмежувались від механічної моторики посекундового просування в хроматичній гамі у Й.С. Баха. У зв'язку з виділеною властивістю інтонаційного співвідношення основних тематичних «вузлів» твору, відзначеного символікою «бахіанства» $i$ жанрових взаємодій, розглянуті Прелюдії Ф. Шопена усвідомлюються як авторськи складений иикл. У ньому істотні ті «наскрізні» лінії смислово-інтонаційного розвитку, які закладені в музичному творі його художньою природою і стилістичною настановою роман-

(C) Бордонюк В. I., 2021 
тичної естетики, що органічно «переплетена» з передсимволістськими показниками мистецтва сучасника «прерафаелітів».

Ключові слова: цикл, ииклізація, тематизм, Прелюдії Ф. Шопена, «Добре темперований клавір» Й.С. Баха.

Bordoniuk Volodymyr Ivanovych, Candidate of Art History, Acting Associate Professor at the Department of Common and Specialized Piano of the Odesa National A. V. Nezhdanova Academy of Music

The concept of cyclization of preludes by $F$. Chopin and their interconnection with a cycle of "The Well-tempered clavier" by J.S. Bach

The purpose of the article is to disclose the unique features of a cycle of Preludes by F. Chopin and to define their internal interconnection with a polyphonic cycle "The well-tempered clavier" by J.S. Bach. The methodology of the work is complex; it lies in the combination of the basics of musicological, artistic, historical and cultural research; it is based on the positions of the intonational approach of Asafiev's school and his successors. The scientific novelty of the research is defined by its analytical approach, concentrated on revealing Bach's and romantic principles of cyclization that lets us determine in Preludes of $F$. Chopin different edges of an image, which are difficult to see while their consideration out of the context of the cycle formation as a whole. Conclusion. In Preludes op. 28 F. Chopin clearly made succession of chromatic 24 keys, with respect to the above-mentioned cycle of J.S. Bach. The structural and semantic interconnection of the prelude-fugue is suggested not only by the character of the idea, that is by something lying out of the "subject" of the work. Orientation on Bach's cycle is "programmed" in the First Prelude and can be traced throughout all 24 plays. However, by establishing an obvious sign of resemblance, $F$. Chopin also differentiated the method of Bach's baroque and logic of romantic aspiration to Beauty, to space immensity of the image. Beauty and spaciousness of overhead sense from the times of the ancient rhetoric were symbolized by the fifth intervalics: the fifth circle determined core interval construction of Preludes by F. Chopin, keeping separate from the mechanic movement of a step progression in the chromatic scale in the works of J.S. Bach. In connection with the underlined intonational junction of the major thematic "joints" of the work, denoted by the symbolism of "bachianism" and genre interconnections, the abovementioned Preludes by F. Chopin are considered as authorial composed cycle. Its essentials are "through" lines of semantic and intonational development, which are embedded in a musical work by its artistic nature and the stylistic setting of romantic aesthetics, organically "interwoven" with the pre-symbolic indicators of the contemporary art of "Pre-Raphaelites".

Key words: cycle, cyclization, thematic invention, Preludes by F. Chopin, "The well-tempered clavier" by J.S. Bach.

Актуальність теми дослідження. Більше 180 років тому були створені Прелюдії Ф. Шопена опус 28. Однак дотепер всілякі питання їх виконавського і музикознавчого трактування 
зберігають свою актуальність. У запропонованих навчальними виданнями характеристиках образності циклу Прелюдій Шопена домінують схвальні епітети на адресу художніх переваг творів і одночасно досить обмежено вказуються ознаки особливостей смислової сфери цієї композиції.

Так, наприклад, щодо образності однієї з Прелюдій у книзі В. Галацької констатується щось самоочевидне, що виникає в процесі слухання, і настільки загальне, що навіть важко співвіднести 3 конкретною п'єсою подібний «опис»: «прелюдія побудована на розвитку ... контрастних образів: світлого, з мелодією, що широко ллється, в крайніх частинах і понуро-похмурого у середній частині» [1, с. 524].

В інших джерелах, у тому числі у підручнику В. Конен, підкреслюється лише високий художній рівень образної подачі ідеї твору без подальших коментарів [2, с. 493]. 3 приводу образності, наприклад відомої Двадцятої прелюдії, В. Конен говорить тільки у зв'язку з жанровими витоками - втіленням ознак похоронного маршу [2, с. 491]. В. Галацька взагалі не згадує про образність цього дивовижного твору, що надихнув С. Рахманінова на ідею його Другого фортепіанного концерту [1]. Шось подібне спостерігається і щодо драматичної Прелюдії № 4, де у разі характеристики образної сфери переважає загальна фраза, а не образно багатогранна характеристика звучання [1, с. 520].

А. Соловцов співчутливо цитує висловлювання Шумана щодо Прелюдій Шопена як «зачатків Етюдів», підкреслюючи «максимальну стислість» кожної з п'єс: «романтичні музичні афоризми», «етюди в мініатюрі» таким є резюме автора монографії [4, с. 403-404]. Але той самий автор категорично не сприймає ідеї авторської циклізації Прелюдій: «Зошит прелюдій, також як і його зошити етюдів, не є циклом у звичайному сенсі слова. Це низка п'єс, об'єднаних спільністю стилю» [4, с. 417].

У чому, безумовно, ми згодні з автором монографії, так це у тому, що це «не цикл у звичайному сенсі слова» (правда, що називати «звичайним»- напевно, традиційний програмно збудований цикл). Але це все з позицій естетики, що категорично не приймає предсимволістське коріння романтизму Шопена.

Спільність композиційного задуму «Добре темперованого клавіру» Й.С. Баха і 24 Прелюдій Ф. Шопена ор. 28 неодноразово ставала об'єктом наукових досліджень. Є добре відо- 
мим з біографії Шопена посилання останнього на бахівський ДТК як пряме джерело-стимул розглянутого циклу. На думку Ю. Кремльова, на відміну від великого поліфоніста, який будував цикл по секундах, тональний план Ф. Шопена побудований по терціях і квінтах [3].

Однак питання про зв'язок цього циклу з глибинними смисловими аспектами символізації бахіанства залишається відкритим, що зумовило актуальність теми цього дослідження.

Мета дослідження - виявлення смислової унікальності циклу Прелюдій Шопена ор. 28 та виявлення їх глибинних взаємозв'язків з поліфонічним циклом «Добре темперований клавір» Й.С. Баха.

Наукова новизна дослідження визначена його аналітичним ракурсом, який зосереджений на виявленні бахівського і романтичного принципів циклізації, що дозволяє виявити в низці Прелюдій Ф. Шопена різні грані образу, які не вловлюються у разі розгляду їх поза контекстом будови циклу загалом.

Виклад основного матеріалу. Як відомо, ідея циклу Прелюдій ор. 28 підказана (в продовження циклізації мініатюр «володарем дум» музичного світу, М. Паганіні в його Каприсах) пролонгацією в романтичні виміри концепції бахівського циклу ДТК як цілісної концепції, яка була для Шопена постійним матеріалом тренажу і одночасно високим взірцем творчості перед виступами на публіці.

Цей романтичний цикл наповнений символізацією бахіанства польського класика, яке одного разу було гордо заявлено автором-початківцем у Першій сонаті c-moll, первинна тема якої - тема-виток, згусток монотематічної побудови цілого вирішена була у вигляді прямої цитати двоголосної Інвенціï c-moll Й.С. Баха. Цю обставину спеціально підкреслив німецький дослідник Д. Кемпер [6], позначивши метод монументальної еклектики романтизму як органічного складника стилю спадщини польського композитора.

Змістовно-структурна співвіднесеність п’єс грунтується на наочно представленому проведенні принципу ладово-тональної спорідненості від Першої до Двадцять четвертої прелюдії.

У сенсі аналогії з бахівським циклом звертають на себе увагу темпо-ритмічні й образно-інтонаційні контрасти пар Прелюдій, що нагадують темпо-ритмічні і жанрові співвідношення «прелюдія - фуга» у циклі Й.С. Баха. Так, відверто 
прелюдійними є Прелюдії №№ 1, 3, 5, 8, 11, 14, 18, 19, 22, 23. У протилежність їм мелодійною визначеністю і завершеністю вирізняється тематизм Прелюдій №№ 2, 4, 6, 7, 9, 13, 15, 17, 20, 21, 24.

Прелюдіï типу «експромтів» - №№ 16 b-moll, 17 As-dur [5]. Прелюдії №№ 12 і 16 вирізняються відверто етюдним характером, тобто в традиційній взаємодії фактури етюду і прелюдії, які нарочито віддалені в жанровому вираженні в інших творах розглянутого опусу. Безумовно, ця етюдність прелюдій вибудовується по типу драматичної етюдності творів самого Ф. Шопена в цьому жанрі, але, безумовно, з «купіруванням» поемних ознак шопенівських Етюдів. Узагальненість і ємність тематизму зазначених Прелюдій №№ 2, 4, 6, 7, 9, 13, 15, 17, 20, 21, 24 співвідносна з узагальненістю і ємністю тематизму фуг Й.С. Баха, тому що їм усім властиві мотивний лаконізм і смислова риторична насиченість в єдності загальнозначущого і індивідуалізованого в інтонаційному наповненні.

Фактурний «потенціал фуги» в Прелюдії № 2 Шопен позначає тим, що вступ теми в основній тональності змінюється в т. 8 у тональності відповіді фуги, в h-moll. За ним слідує репризне проведення теми в основній тональності (т. 14), але в характері «тональної відповіді», тобто як би в поєднанні в такому третьому проведенні теми ознак репризного і розробкового розділів бахівської Фуги. Більш того, два останні такти демонструють характерне для коди фуги ритмічне збільшення показового і впізнаваного мотиву теми.

Прикладом ємності тематизму і єдності в ньому узагальнюючого та одинично-індивідуалізованого сенсу може служити Прелюдія № 4. У ній образ страждання-скорботи представлений «паралельними рядами»: 1) «загальний» тип catabasis у «жорсткому риторичному ході» хроматичної послідовності в басу; 2) ознаки інтонації lamento у вираженні страждання, що особистісно відчувається; 3) нарешті, послідовність септакордів як специфічно романтичної і шопенівської гармоніï, що передає індивідуалізоване відчуття невизначеності та тендітності моменту-образу. У фактурі цієї Прелюдії також є «симуляція імітації, оскільки друге речення (т. 5) вибудовано від висотності $\mathrm{a}^{1}$, що розташована на секунду нижче від вихідного $\mathrm{h}^{1}$. Друге речення від т. 19 складного періоду форми п'єси показує рівень fis, тобто висотність «відповіді» теми фуги. 
Прелюдія № 6 за загальним фактурним рішенням справедливо називається «віолончельний романс», у ній чують насамперед жанровий відблиск «пісні без слів». I це все правильно. Але є в цій п’єсі і висотно-ритмічне остинато, яке пов'язують $з$ одним із втілень «музики дощу», оскільки цей пласт верхнього голосу, що «акомпанує», відокремлений від акордової підтримки романсової фактури. Він являє контрапункт, що утворює контрастно-поліфонічне утворення, яке безпосередньо не має відношення до простоти «інструментальної пісні-романсу», але створює щось більш рефлексивне, те, що виникає завдяки поліфонічним поєднанням ліній. Так вибудовується «натяк на поліфонію» у вигляді quasi-iмітаційних структур-сенсів, що були задіяні у Другій і Четвертій прелюдіях.

Принцип контрасту безпосередньо-жанрової та інтелектуально-узагальненої музики, який є характерним для побудови «малих циклів» бахівських Прелюдій і фуг, спостерігається у співвідношенні Прелюдій Шопена: №№ 1-2, 3-4, 5-6, а потім 8-7, 10-9, 12-11, 14-13, 19-20. Послідовність контрасту «прелюдійних Прелюдій» та Прелюдій, що містять тематичну визначеність мелодично вираженого типового звороту, затверджується і за допомогою «емансипації» прелюдійних п’єс від зв'язку в циклі прелюдія-фуга, і в переміщенні від № 7 «прелюдійних Прелюдій» на місце, що відповідає місцю фуг у циклі Й.С. Баха.

Цей прояв комбінаторики в розвитку структури шопенівських Прелюдій за допомогою співвідношень бахівського і романтичного принципів циклізації дозволяє виявити в низці п’єс різні грані образу, що не уловлюються у разі розгляду їх поза контекстом будови циклу загалом.

Так, Восьма прелюдія є декларацією романтичної баладності у специфічному індивідуалізовано-шопенівському втіленні фонізму, барвистості, багатозвуччя фактури. Але водночас ця Прелюдія виступає і як перша серед «парних» номерів, яка порушує встановлений у №№ 1-6 ритм парних взаємодій прелюдійно-імпровізаційного і тематично-завершеного викладення. У «парі» Прелюдій №№ 7-8 тематично більш вираженою є п’єса № 7. Але вона виявляється лише «введенням» у загальний потік романтичного пориву № 8. Патріотичне почуття композитора, який болісно і віддано любив свою рідну Польщу, який відобразив грані іiі образу в 
мазурочних зворотах Сьомої прелюдії, що сприймалися лише як складник, компонент загального романтичного пориву до краси і свободи. I останній, що ріднив романтиків усіх країн і націй, відображений у розлогій і масштабній Прелюдії № 8. Отже, емблематична жанр-тема - Прелюдія № 7, вихідний мотив якої утворює інверсію основного мотиву № 2. Тематичний матеріал Прелюдії № 8 також розвиває зазначені мотиви.

Зазначений тип образної взаємодії Сьомої та Восьмої прелюдій певною мірою проявляється в інтонаційно-образному вираженні п’єс №№ 16 і 15, хоча і на новому рівні, з іншою смисловою акцентуацією.

Так, П'ятнадцята прелюдія, образ якої багатьма мистецтвознавцями асоціюється 3 «прелюдією капель» в описі Ж. Санд, безумовно, містить національно-польський елемент у вигляді мазурочного звороту - на 4/4 (пор. аналогічний прийом у III частині Третьої сонати). Ефект остинато явно співвідносить цю Прелюдію з № 6.

Узагальненість мелодично вираженого тематизму, що нагадує риторичну спільність тем фуг Й.С. Баха, в які «вводять» прелюдійно-етюдні п’єси, чітко позначена в №№ 1-2, 3-4, 5-6 та зберігає цю послідовність аж до № 7.

Із Сьомої прелюдії проявляються деякі «порушення» в ритмічній зміні пар прелюдій, що намітилася: наступні номери, хоча і зберігають вищевказану парність угруповання, яке підтримується спорідненістю паралельних тональностей, за їхньою інтонаційно-жанровою орієнтацією як би «міняються місцями».

В усталеному ритмі змін «прелюдійних» п'єс і п’єс (№№ 1-2, 3-4, 5-6), тематизм яких має ознаки тем фуг, зміна такої послідовності в № 7-8, 9-10 сприймається як щось навмисне й образно значуще. В цьому полягає, на наш погляд, глибокий сенс: універсальність, узагальненість, що концентруються у фугах Й.С. Баха як складник точки опори його мислення, у Ф. Шопена виступають лише як «точки відштовхування», що долається динамікою загального устремління розвитку циклу до маніфестації романтичного «Пориву в Нікуди» в № 24.

Починаючи від Прелюдії № 8 «прелюдійні» п’єси посідають місце змістово-опорних, подібне тим, які відзначені номерами 2, 4, 6 на початку циклу. Тут на перший план виходить романтичне бачення дійсності - 3 вищевідзначеною 
баладністю інтонацій, 3 підкресленням квартових «закликів» мелодійних послідовностей «філософського питання», 3 барвистістю і «легкістю» фактури власне шопенівських творів. Додамо також динаміку тонального плану романтичного монологічного твору, що дає медіантові «переходи» ладово контрастуючих тем-образів. Сукупна дія цих загальноромантичних та індивідуалізовано-шопенівських засобів створює міцний «драматичний вузол», що відзначає перелом, новий етап у розвитку циклу.

Так вимальовуються контури романтичного сприйняття бахіанства, де існує зміна акценту в смислових рядах бахівського мистецтва: самодостатність руху, цільові віхи якого «вуалюються» $\mathrm{i}$ «підміняються» жанровими моделями буттєвості, обходячи високу абстракцію, відображену в риториці фуг.

У парах № 7-8, 9-10 зберігається членування «ввідної основної» п'єс циклу, подібно предюдійності й узагальненості мелодично вираженого тематизму в парах № 1-2, 3-4, 5-6. Але прелюдії №№ 7, 9 втрачають якість «прелюдійності», а № 8, 10 далекі від моно-тематичної строгості №№ 2, 4, 6, що асоціюється з узагальненістю фуг Й.С. Баха.

I все ж значеннєва вага вищевказаних номерів не викликає сумнівів і на новому рівні темпо-жанрової та інтонаційно-образної подачі ми вловлюємо усталений в №№ 1-6 ритм коливань смислової концентрації тематизму пар п'єс.

Висновки. У Прелюдіях ор. 28 Ф. Шопен чітко склав послідовність хроматичних 24 тональностей, у нагадування згаданого циклу Й.С. Баха. Структурне і смислове співвідношення «прелюдія-фуга» підказано не тільки характером задуму, тобто чимось, що лежить поза «матерією» твору. Установка на бахівський цикл «запрограмована» в Першій прелюдії і простежується протягом усіх 24 п'єс. Але, заклавши очевидний знак подоби, Ф. Шопен спеціально також і розмежував метод бахівського бароко і логіку романтичного устремління до Краси, до космічної масштабності образу. Краса і просторовість надземного сенсу від часів стародавньої риторики символізувалася за допомогою квінтової інтерваліки: квінтове коло визначило стрижневу інтервальну конструкцію Прелюдій Ф. Шопена, які відмежувались від механічної моторики посекундового просування в хроматичній гамі у Й.С. Баха.

У зв'язку з виділеною властивістю інтонаційного співвідношення основних тематичних «вузлів» твору, відзначе- 
ного символікою «бахіанства» і жанрових взаємодій, розглянуті Прелюдії Ф. Шопена усвідомлюються як авторськи складений цикл. У ньому істотні ті «наскрізні» лінії смислово-інтонаційного розвитку, які закладені в музичному творі його художньою природою і стилістичною настановою романтичної естетики, шо органічно «переплетена» 3 передсимволістськими показниками мистецтва сучасника «прерафаелітів».

Концепція циклізації Прелюдій, закладена асоціюванням з «Добре темперованим клавіром» ЙС. Баха, привносить образам, що не мають чіткої літературної програми, висоту ідеального злету, самодостатнього у виразному звучанні: трагічна або «пасторально-світла» якість образу конкретної п'єси обіймається «давідсбундом» прилученням до світу Піднесених і цим нескінченно прекрасних образів. I в цьому плані суворість інтерпретації Прелюдій Ф. Шопена, які граються навіть окремими п'єсами або малими циклами, виграє в розумінні виконавцем їх елітарно-художньої призначеності.

\section{СПИСОК ЛІТЕРАТУРИ}

1. Галацкая В. Музыкальная литература зарубежных стран. Москва : Музыка, 1974. 560 с.

2. Конен В. История зарубежной музыки. Москва : Музыка, 1965. Вып. 3. 528 с.

3. Кремлев Ю. Фредерик Шопен: очерк жизни и творчества. Москва : Музыка, 1971. 607 с.

4. Соловцов А. Ф. Шопен. Москва : Музгиз, 1960. 468 с.

5. Chomiński J. Chopin. Krakyw : PWM, 1978. S. 260.

6. Кдmper D. Die Klaviersonate nach Beethoven. Von Schubert bis Skrrjabin. Darmstadt : Wissenschaftliche Buchgesellschaft, 1987.

\section{REFERENCES}

1. Galatskaya, V. (1974). Musical literature of foreign countries. Moscow: Muzyika [in Russian].

2. Konen, V. (1965). The history of foreign music. Moscow: Muzyika [in Russian].

3. Kremlev, Yu. (1971). Frederic Chopin: sketch of the life and work. Moscow: Muzyika [in Russian].

4. Solovtsov, A. (1960). F. Chopin. Moscow: Muzgiz [in Russian].

5. Chomiński, J. (1978). Chopin. Krakyw: PWM [in Polish].

6. Kдmper, D. (1987). Die Klaviersonate nach Beethoven. Von Schubert bis Skrrjabin. Darmstadt: Wissenschaftliche Buchgesellschaft [in German]. 